Sara Esmaelzadeh Saeieh ${ }^{1}$, Zohreh Mahmoodi ${ }^{1}$, Katayoun Salehi' $^{2}$, Kourosh Kabir ${ }^{3}$, Mansoureh Yazdkhasti ${ }^{1 *}$

1 Department of Midwifery, Assistant Professor, social determinant of health research center, school of medicine, Alborz University of Medical Sciences, Karaj, Iran ${ }^{2}$ Ms in Midwifery, Alborz University of Medical Sciences, Karaj, Iran ${ }^{3}$ Department of Community Medicine ,M.D, Associate professor, social determinant of Health Research Center, School of Medicine, Alborz University of Medical Sciences, Karaj, Iran

*Corresponding Author: Alborz University of Medical Sciences, school of medicine: Blvd Hassan Abad, Township Oaj, Karaj, Iran

Tel: 026-34336007

E-mail: M.Yazdkhasti@abzums.ac.ir

\section{Teaching Methods for Students Through Role-Playing and Buzz Group Learning Methods Based on Adult Learning Theory}

\author{
Received:13 Mar. 2018; Accepted:22 May 2018
}

Background: Teaching is a purposeful activity and aims to enhance people's learning. Today, with the advancement of science in medical universities, the use of collaborative, problem-solving and student-centered approaches has been emphasized. The purpose of this study is to review the teaching methods of students through role-play learning and Biz group techniques based on adult learning theory.

Materials and Methods: In this review article was searched of numerous scientific databases including: SCOPUS, PubMed, SID, IJME (2000-2015). Key words were based on MESH Role playing, Buzz group, Adult learning theory). Step to, step search was done. The number of articles reached 23 with consider to including criteria.

Results: Learning methods should be tailored to the needs, individual characteristics and socio-cultural context of individuals. On the other hand, it is so arranged and so diverse that it provides the means to adapt them to their living and working environment. Choosing a learning style varies depending on the different circumstances and according to the goals, motives, people, facilities, time, tools and tools used to learn individuals. Role play and Buzz group are problem-based learning and participatory learning that has been changed to use in the teaching of emotional domains. The role play and Buzz group technique leads to student learning through motivational and challenging learning.

Conclusion: Organizing materials and the need for professors to become acquainted with dynamic and participatory learning platforms, based on interactive educational patterns, cause students to learn better.

Keywords: Adult Learning Theory, Buzz Group, Role-Playing 


\section{شيوههاى آموزش به دانشجويان از طريق شيوههاى يادَّيرى ايفاى نقش و

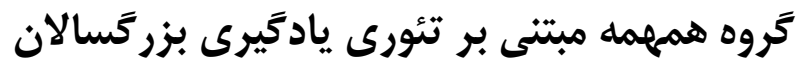

تاريخ دريافت مقاله:

حك)

مقدمه: تدريس، فعاليتى هدفمند است و هدف از آن ارتقاى يادگيرى افراد است. امروزه با بيشرفت علوم در دانشخاه هـاى علوم يزشكى استفاده از روش هاى مشاركتى، مبتنى بر حل مساله و دانشجومحور مورد تاكيد قرار گرفتـه اسـت. هـدف از اين مطالعه مرورى بر شيوههاى آموزش به دانشجويان از طريق شيوههاى نوين يادگيرى ايفاى نقش و گروه همهمــه مبتنى بر تئورى ياد گيرى بزر گسالان مىباشد.

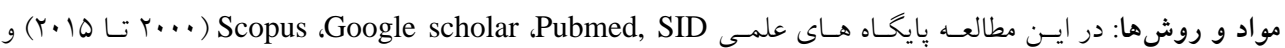
مقالات منتشر شده در مجلات معتبر داخلى در زمينه آموزش يزشكى از جمله IJCME و كامهاى توسعه آموزش يزشـكى با استفاده از كليد واثههاى : Adult learning theory ، Buzz group ، Role playing ، Education ، مورد جستجو قرار كرفت. بنابر جستجوى انجام شده سץ مقاله مرتبط با توجه به هدف يزوهش انتخاب گرديد.

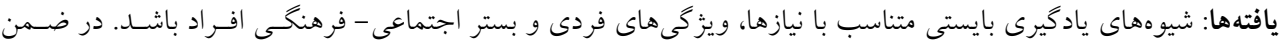

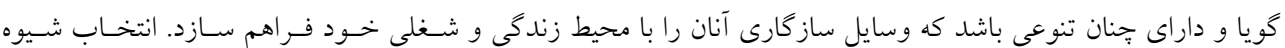
يادگيرى بسته به شرايط مختلف و با توجه به هدفها، انكيزه ها، افراد متفاوت، امكانات، زمان، وسايل و ابزار مورد اسـتفاده در ياد گيرى افراد، متفاوت است. ايفاى نقش و گروه همهمه از جمله يادگيرى مبتنى بر حل مسئله و مشاركتى است كه بـه. سمت استفاده در آموزش حيطههاى عاطفى تغيير يافته است. روش ايفاى نقش و گروه همهمه به لحاظ يادكيرى انخيزشى و جالش بر انخيز مى تواند به ارتقاى ياد گيرى دانشجويان كمك نمايد و به ياد گيرى آنها عمق بيشترى بخشد. نتيجه گيرى: سازماندهى مطالب و لزوم آشنايى اساتيد با راهبردهاى يادگيرى بويا و مشاركتى بر حسب الخوهـاى آموزشىى تعاملى سبب بارش افكار و يادگيرى بهتر دانشجويان مى گردد.

$$
\text { كلمات كليدى: تئورى يادگيرى بزر گسالان، گروه همهمه، ايفاى نقش }
$$

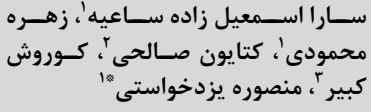

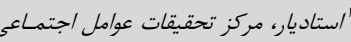

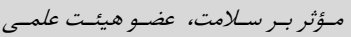

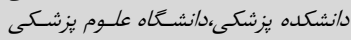

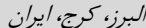

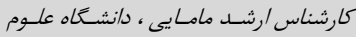

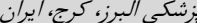

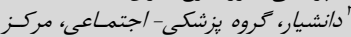

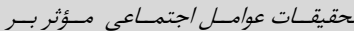

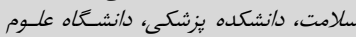

\section{يزشكى البرز، كرج، ايران}


ارتقاى يادكيرى كمى شايانى مىنمايد . ‘ّدر اين ميـان، شـيوهــاى

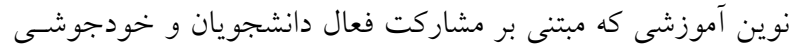
آنان در فرايند يادكيرى گردد مى تواند به بارش افكار آنـان انجاميــهـ

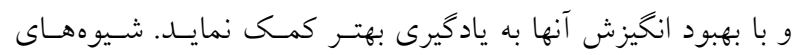

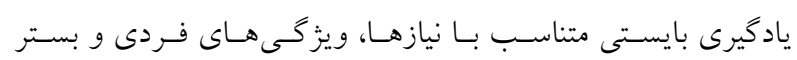

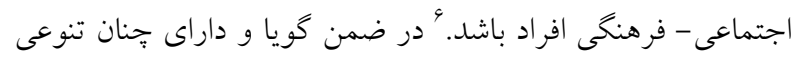

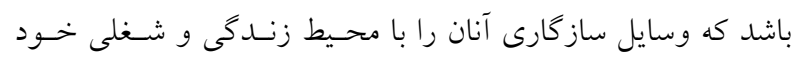

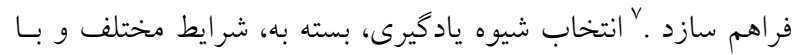

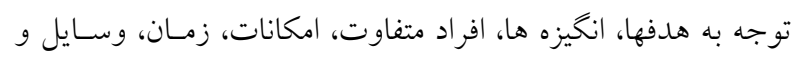

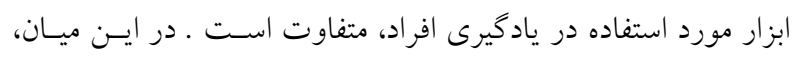

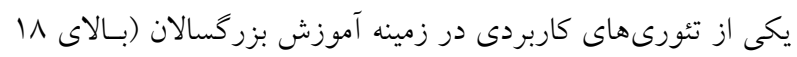

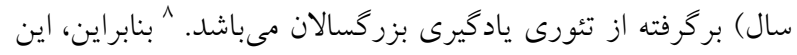

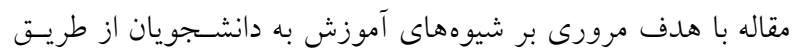
شيوههاى نوين يادكيرى ايفاى نقش و گروه همهمه مبتنى بر تئسورى يادگيرى بزركسالان تدوين گرديد.

\section{مواد و روشها}

در اين مطالعه بِايخـاه هـاى علمس Pubmed، Google scholar،

Scopus و مقالات متتشر شده در مجـلات معتبـر داخلسى در زمينـه

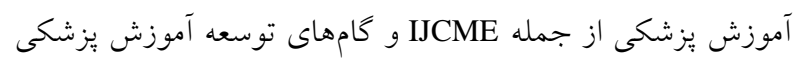

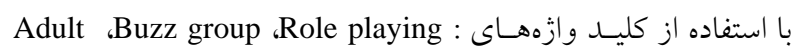
Education dlearning theory

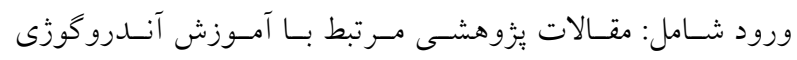

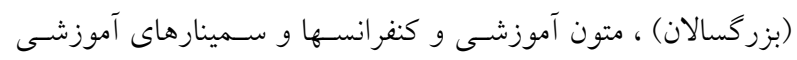

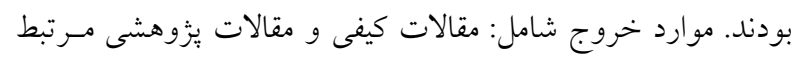

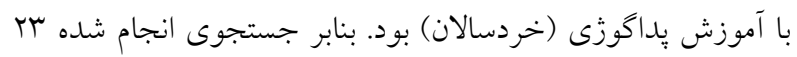
مقاله مرتبط انتخاب كرديد.

\section{تئورى يادگيرى بزرخسالان}

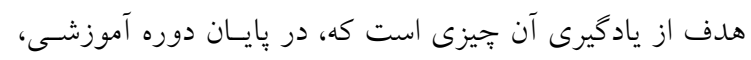

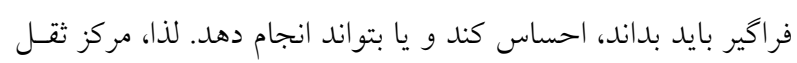

$$
\text { يادكيرى، فراكير است. }
$$

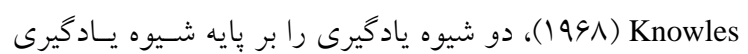

آموزش، فرايند متقابلى است كه موجب ارتقاى يادكيرى شده و

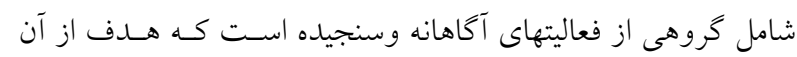

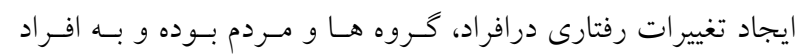

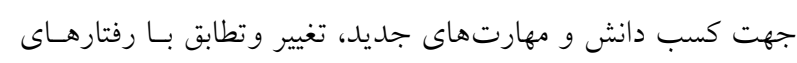

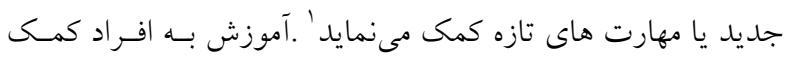

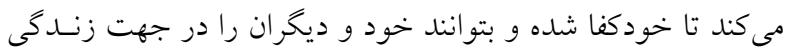

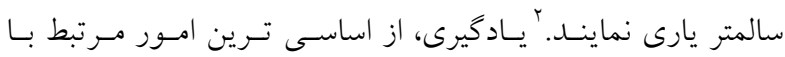

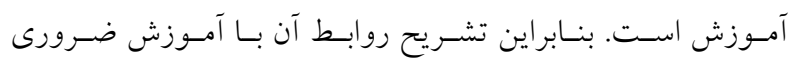

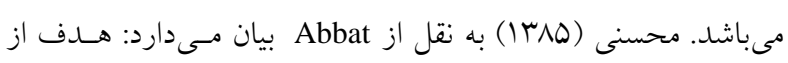

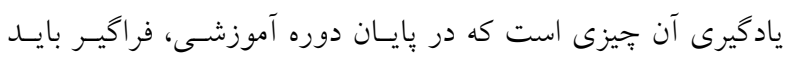

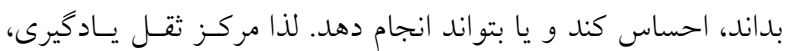

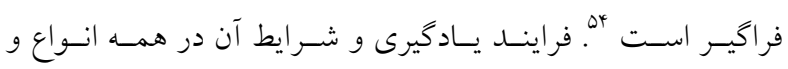

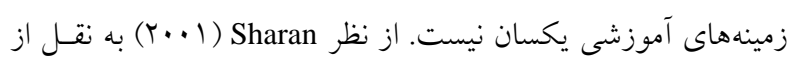

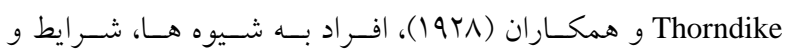
موقعيت هاى مختلف ياد مى كيرند.

الكوى كاربردى در حوزه آموزش مستقيم، الكوى بيش سيش سـازمان دهنده است. منظور از يبش سازمان دهنده، يك موضـوع يـا مفهـوم

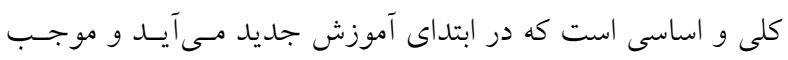

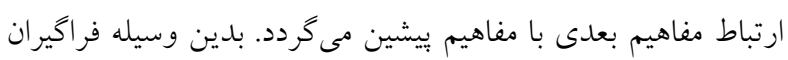

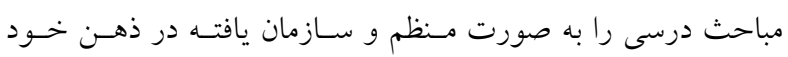

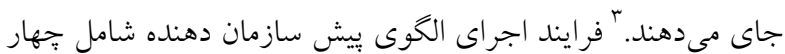

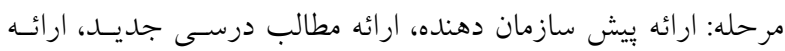

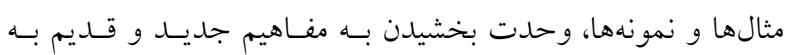

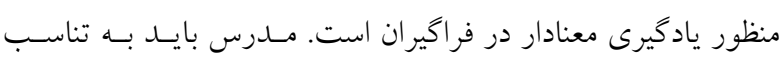

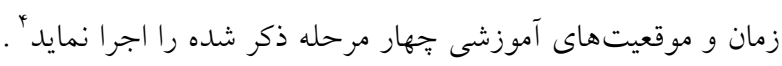

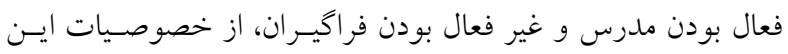

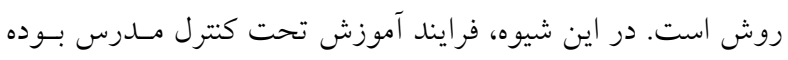

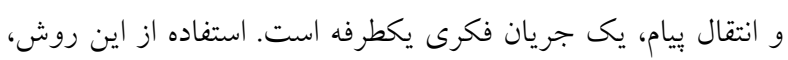

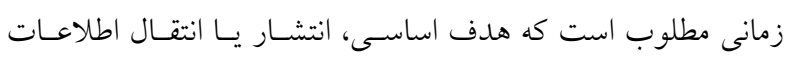

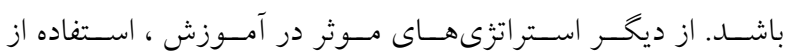

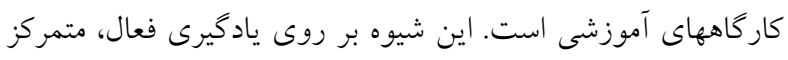

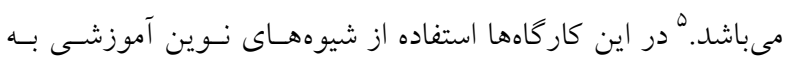




\section{يادگيرى فرد محور}

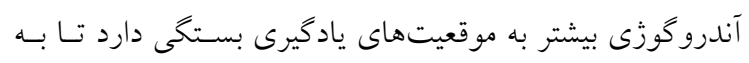

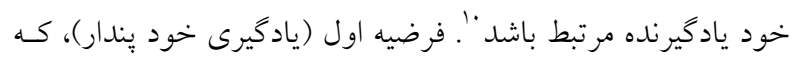

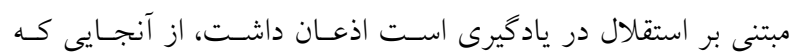
بزرگسالان كنترل و مديريت جوانب متعدد زندگى خود را بر عهـده

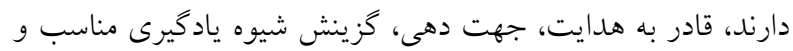

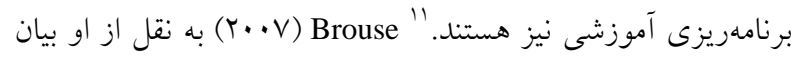

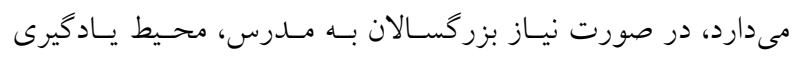

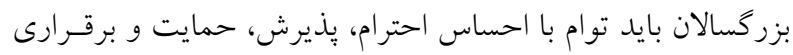

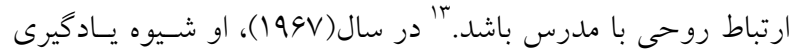

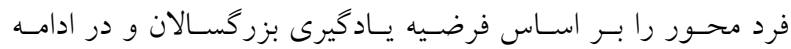

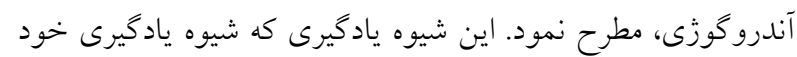

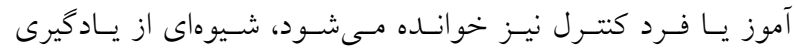

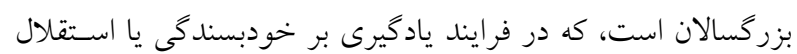

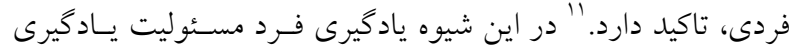
خويش را بر عهله داشته و متعهدانه و فعالانه در اين امـر مشـاركت

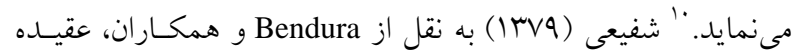
دارند كه احساس خودبسندكى، ييش نياز مهمى بــراى تغييـر رفتـار

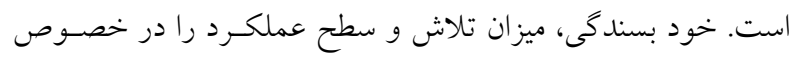

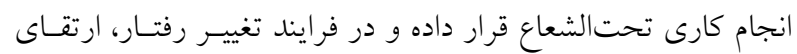
خودبسندگى بسيار قابل اهميت است. در اين راستا اهداف ياد گيرى

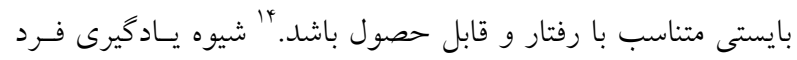

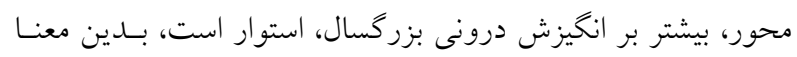

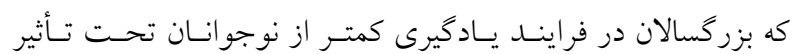

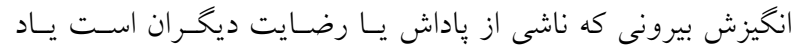

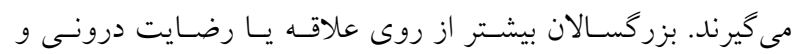
برحسب نياز خود، ياد گرفته و به لحساظ داشـتن تجـارب قبلى در

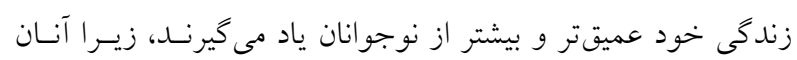
داراى دامنه اى از تجربيات غنى، بيشتر از نوجوانان بوده واين مسئله

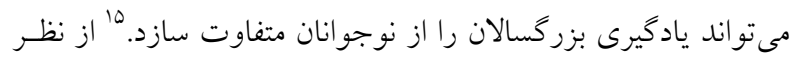
Knowles زندگى روزانه است و بدون نياز به كلاس و مدرس و با استفاده از

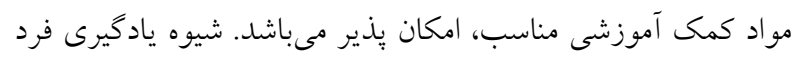

بزركسالان (1/ سال تمام)، مطرح كرد. ايسن دو شسيوه يـادكيرى بـر

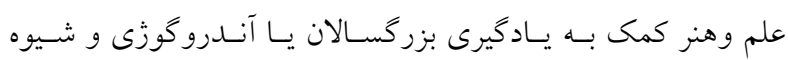
ياد گيرى فرد محور تاكيد دارد. 'ال منظور از آندروكوزى، علم و هنر كمى به يادگيرى بزركسـالان

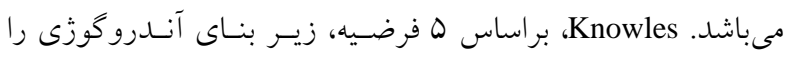

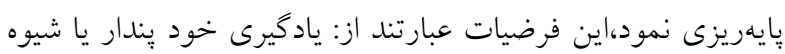

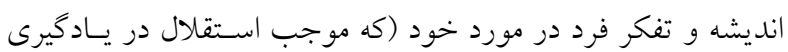
فرد مى شود). فرد، به عنوان منبع تجارب زندگى (فرد غنى از تجارب زنـدكى

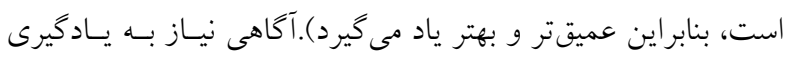

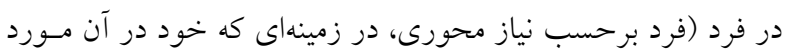
احساس نياز مى كند، به ياد گيرى مى يردازد). علاقه فـرد، بـه كـاربرد دانش بدون واسطه (فرد در زمينه يادگيرى، هميشه بـه مــدرس نيـاز

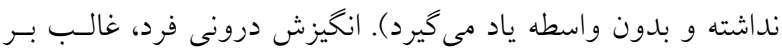
انخيزش بيرونى (از آنجايى كه فرد برحسب نياز و علاقـه خــود يـاد

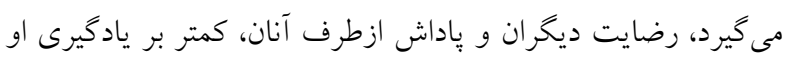

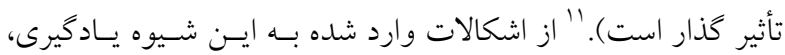
مختص بــودن آن بـهـ بزرگسـالان و قرارگــــن كامـل آن در مقابـل

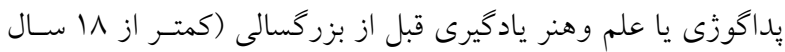

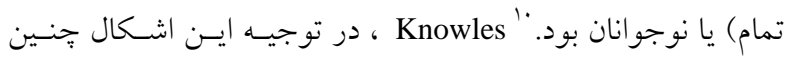

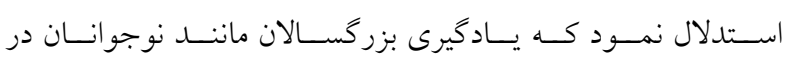

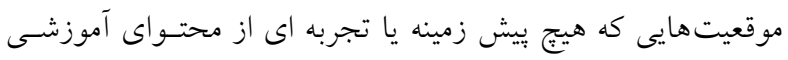

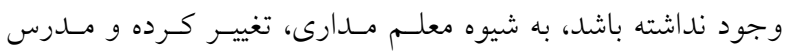

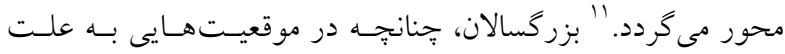

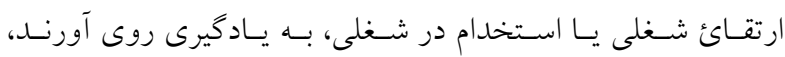

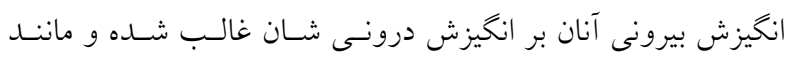
نوجوانان بيشتر داراى انخيزش بيرونى در زمينه ياد گيرى مسى شئسوند.

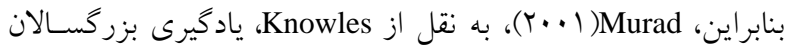

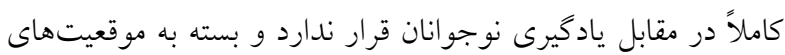
مختلف ياددهى - يادگيرى در اين دو خـروه، شـيوه يـادگيرى تغييـر مى نمايد. 
Bereit, Carl and Engleman , Seigfried اور كان براى برنامههاى تحصيلى دوره ييش دبستانى باهدف كسـب مهارتهاى بايه در رياضى، زبان، و تسلط بر علائم ديدارى، مفاهيم و رنخهاى اساسى بايه كذارى شد. آموزش مسـتقيم، در حـال حاضـر

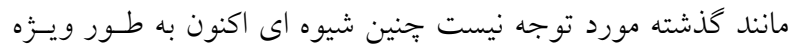
جهت ارتقائ ياد گيرى دانش اجرايى، در مهارتهاى ساده و بيّجيده

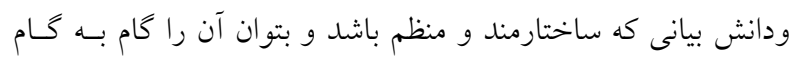

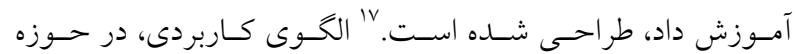

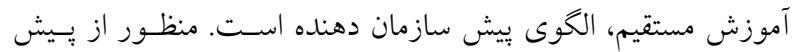

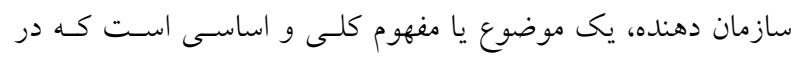

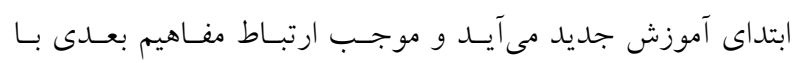

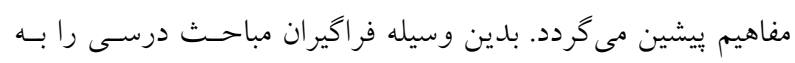
صورت منظم و سازمان يافته در ذهن خود جاى مى دهند.” فرايند اجراى الكوى ييش سازمان دهنده شامل جهار مرحلسهى: ارائه يِيش سازمان دهنده، ارائه مطالـب درسسى جلديــ، ارائسه مثالهـا ونمونه ها، وحدت بخشيدن به مفـاهيم جديسـا و قـــيم بـهـ منظـور

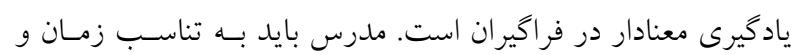

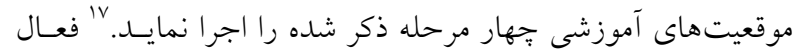

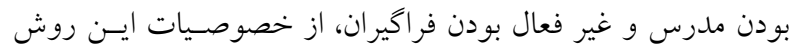
است. در اين شيوه، فرايند آموزش تحت كنترل مدرس بوده و انتقال

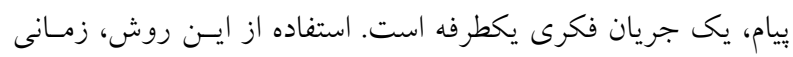
مطلوب است كه هدف اساسى، انتشار يا انتقال اطلاعات باشد. از ديخر استراتزىهاى مـوثر در آمـوزش بهداشـت، استفاده از كارگاههاى آموزشى است. اين شيوه بر روى يادگيرى فعال، متمركز

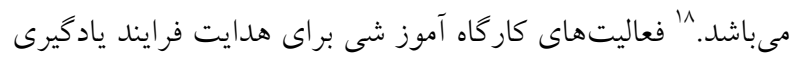

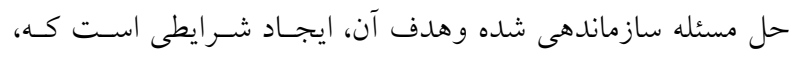

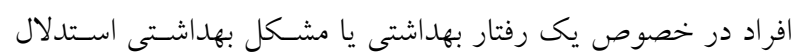
نمايند. 19

\section{كروه حمايتى}

كروه حمايتى مىتواند در گارگاههـاى آموزشسى مـورد اسـتفاده

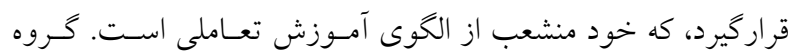
حمايتى ابتدا با سخنرانى مقدماتى مدرس بر اساس اهـداف كلى از
محور، اهداف متغيرى دارد كه شالوده آن، بر ظرفيت و توانـايى يـاد كيرند ان استوار است. (1991) Knowles \& Tough انسانى كه داراى حس مسئوليت بــذيرى در يـاد گيرى اسـت، شـيوه

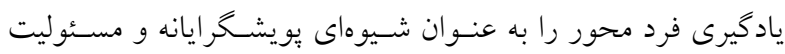
مدار در نظر گرفتند، بنابراين مسئوليت مدارى فردى يكى از اهـ اهـداف اين شيوه ياد گيرى است." هدف دنبـال شـده ديخـر در ايسن شـيوه ياد گيرى، انتقال جهت ياد گيرى از شيوه رسمى به غير رسمى اسـت.

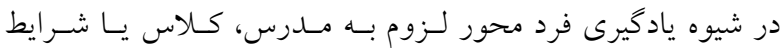
يادگيرى خاص مانند آنجه در شيوه رسمى يادكيرى لحاظ مى شــود،

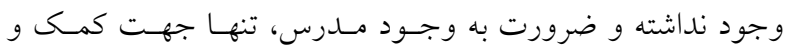
هدايتدهى بزركسالان است تا در صورت نياز بزرگسـال و بنـا بـر

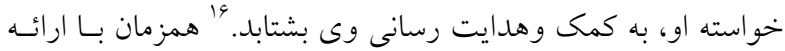

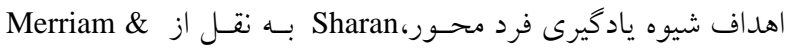
Caffarella

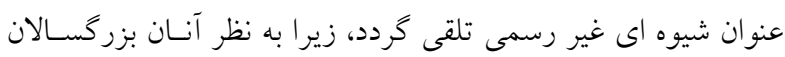
كمتر به مواد آموزشى مقدماتى و تشويق مدرس جهت ئى يادكيرى نياز

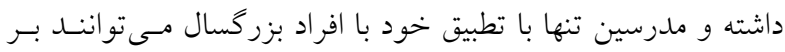

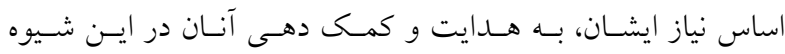
بيردازند. مدرس در اين شيوه يادگيرى، به حمايست، راهنمـايى و در

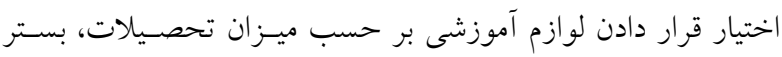

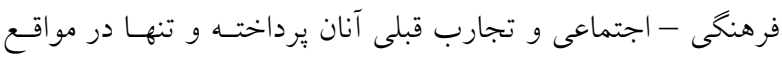
لزوم آنان را در يادگيرى راهنمايى مىنمايد.'

\section{سخخر انى}

شيوه سخنرانى زير كروه آموزش مستقيم است. آموزش مستقيم

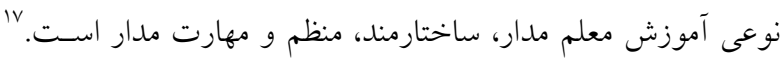

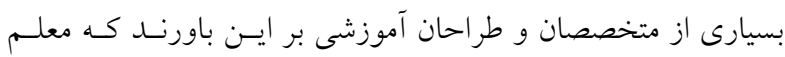

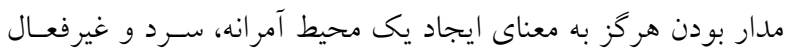

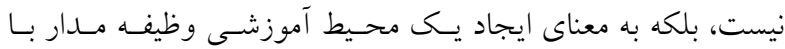
انتظارات بالا، براى انجـام وظــايف اسـت در جنـين شـيوهاى افـراد

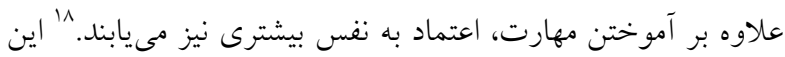

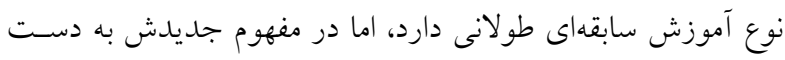


نيازهاى عاطفى او مدنظر قـرار كرفتـه، بتوانـــ افكـار و احساسـات،

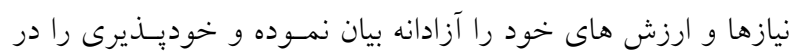
خود تقويت نمايد.

\section{شيوههاى آموزشى تكميلى}

در شيوه بِانل، تعدادى از متخصصين در مقابـل حاضـرين قـرار كرفته و با يكديخر در مورد موضوع خاص و در در ارتباط با حاضرين در جلسه، بحث مى نمايند. در جريان بحــث ميـان اعضـا، كـه ابعـاد مختلف يك موضوع مورد تجزيه وتحليل قرار مسى گيسرد، حاضـرين با كوش دادن به مباحث عنوان شده، از آن بهره برده، به دانشافزايى تركي

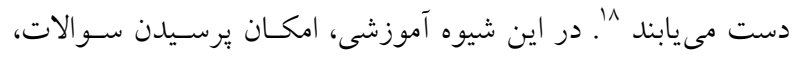

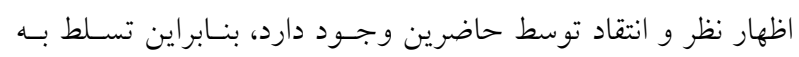

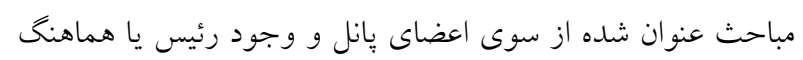
كننده اى ماهر و مسلط به مباحث ضرورت دار دارد. 19

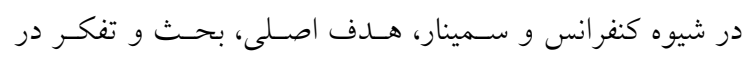
مورد موضوع خاصى است. كنفرانسها و سمينارها، گروهبندىهـاى وسيعى هستند كه از اشخاصى تشكيل مىشوند كه داراى علائست يـاـ

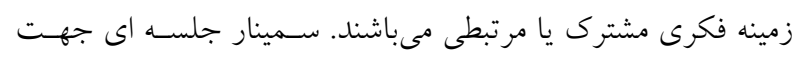

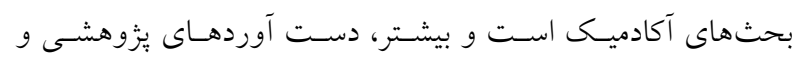

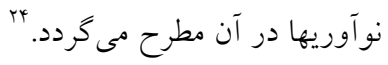

كنخره داراى ابعاد گسترده در سطوح ملى و يا بين المللى است،

كه درآن گروه زيادى شركت داشـته و حالـت ادوارى دارد. از نظـر

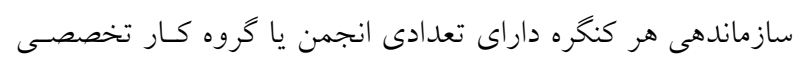

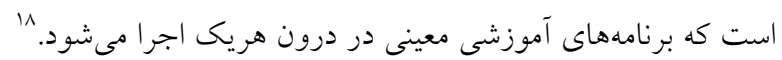

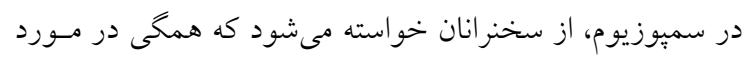
جوانب فرعى يكى موضسوع صـحبت نماينـــ بطوريكـه مطلـب هـر

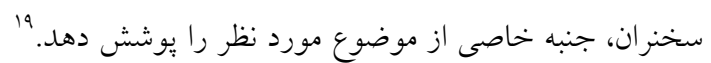

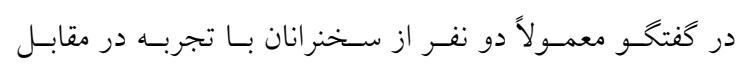

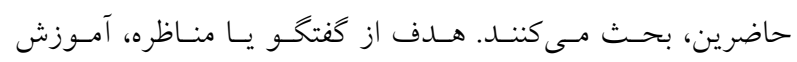

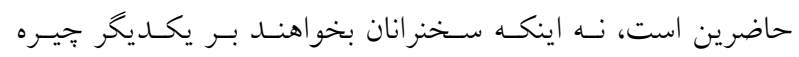
شوند.r. إضرين
يِيش تعيين شده در هر جلسه آغاز شده و سيس افـرادى كـه داراى تجارب مشترك در مورد موضوعات مطرح شــده هسـتند، شسيرازه جلسه را در دست مى گيرند. در طى جلسه مـدرس تنزها بـه عنـوان

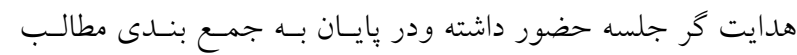

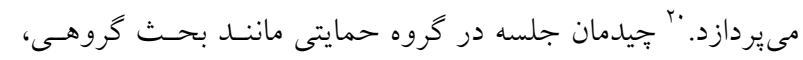
دايرهوار است تا افراد به راحتى در ديد يكديخر قرار گرفته و ارتباط جهره به جهره داشته باشند. روش گروه حمايتى، براى كـلاسهـايى

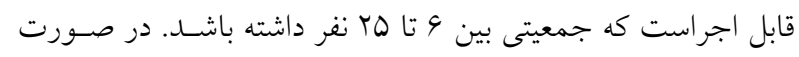

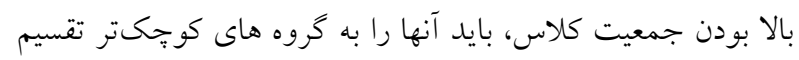
نمود. الكوى آموزش تعاملى بر رشد آكاهى هــاى مربـوط بـه فراينـــ

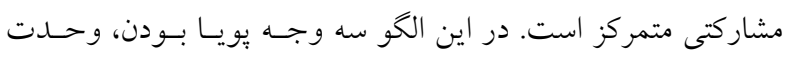
بخشيدن و تعالى در مركز ثقل فعاليت ها قرار دارد. الكوى آمـوزش تعاملى، علاوه بر كسب معرفت علمى و اجتماعى بر اساس برورش

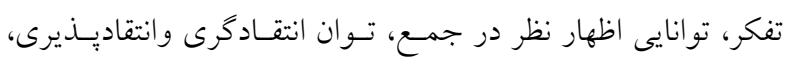

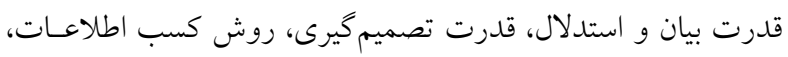

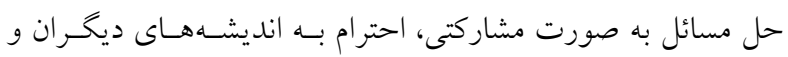
تحمل عقايد ديكران استوار است. بَاز روش گروه حمـايتى، عـلاوه

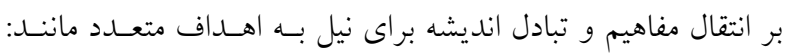

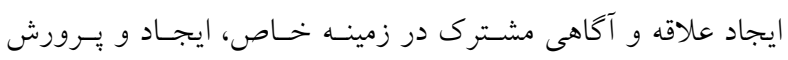
تفكر انتقادى در جمع، تقويت قدرت بيان واستدلال، تجزيه، تحليـل

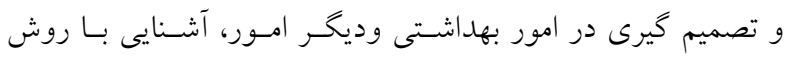
كسب اطلاعات، حل مسائل و ايجاد رابطه مطلوب اجتماعى استفاده مى گ كرد. صرفهجويى در وقت و هزينه، از نتايج حاصل از اجراى كارگـاه هاى آموزشى گروهى است. در اين روش، تمامى افـراد از امكانـات

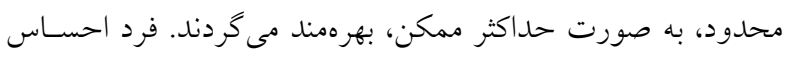

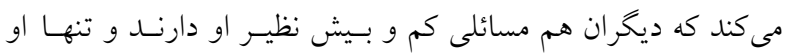

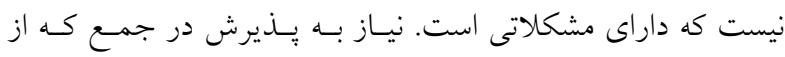

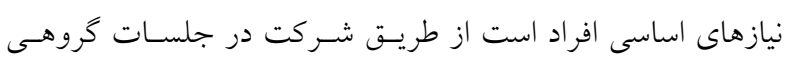

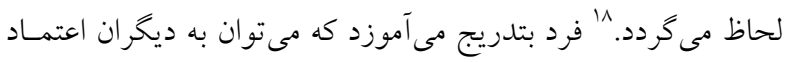
كرد، مسائل و مشكلاتش را از ديد ديخران مورد بررسى قرار داده و به اين ترتيب در توانمندى خويش از طريق شـناخت بيشـتر خــود، بيشرفت مىنمايد. فرصتى فراهم مى گردد كه احساس امنيت و ساير 
فراكيران به بذيرش آن رغبت بيدا كنند. انتخـاب ايفـاكران و تعيسين

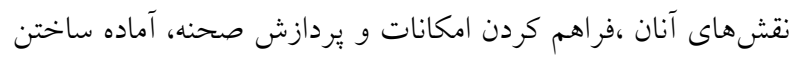

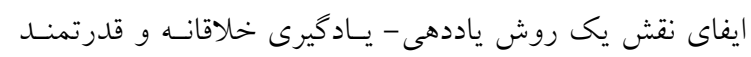
مشاركت كنند كان براى مشاهده، توضيح مختصر در مورد موضوع و و

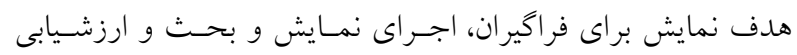

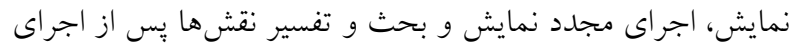

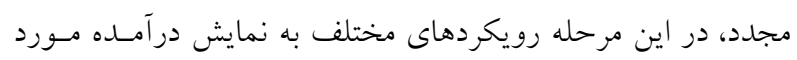

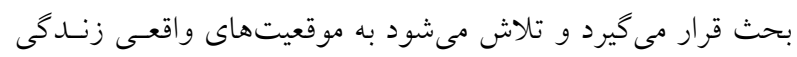

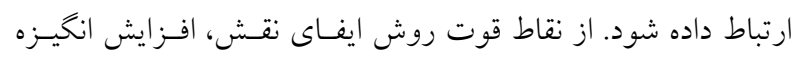

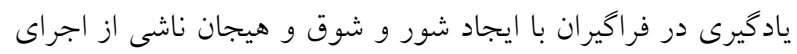

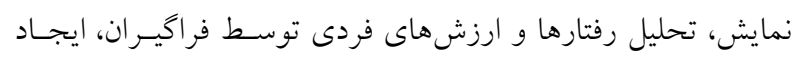

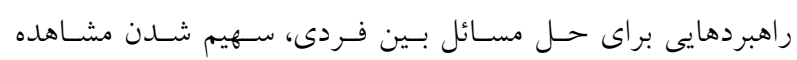

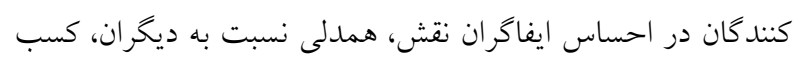

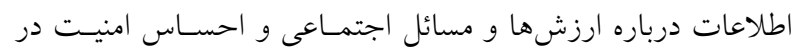

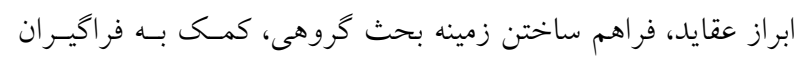

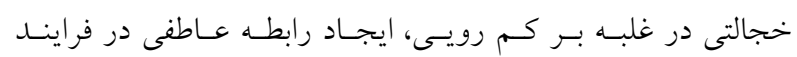

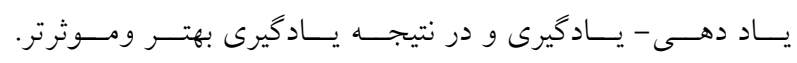

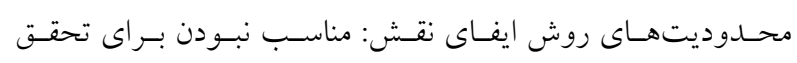

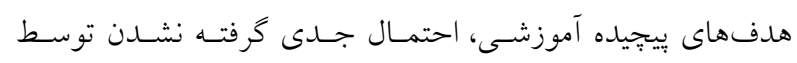

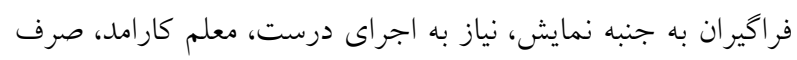
وقت كافى و تهيه تداركات مىباشد.

\section{كروه همهمه}

يكى از فنون تدريس مشاركتى مى باشد. كلاس بـهـ كـروه هـاى

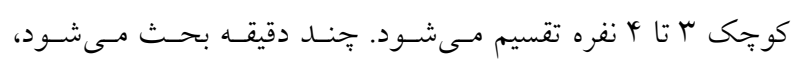

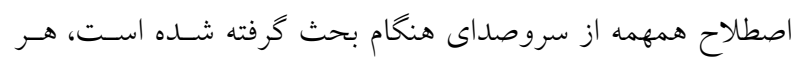

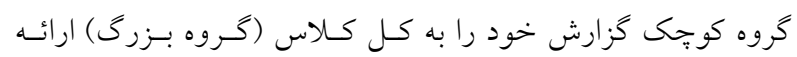

\section{بحث و نتيجه گيرى}

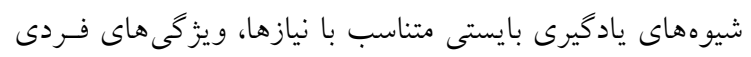

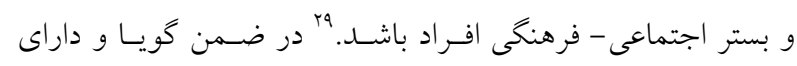

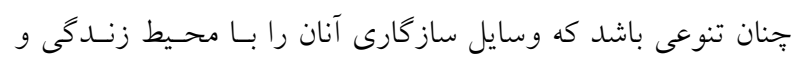

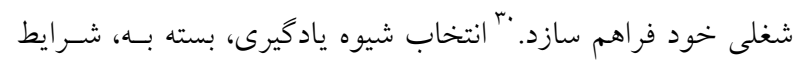

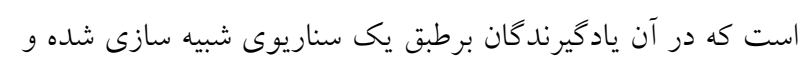

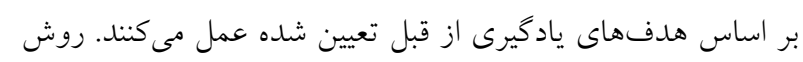

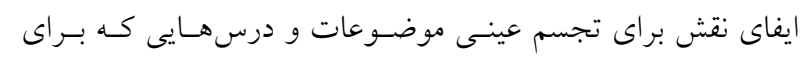

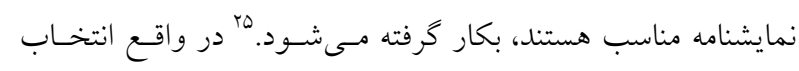

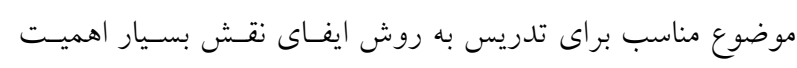

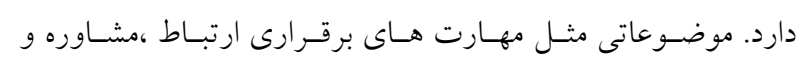

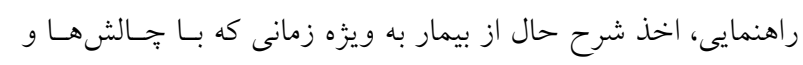

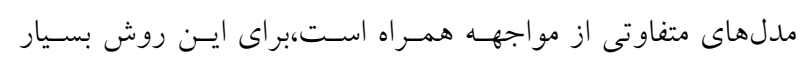

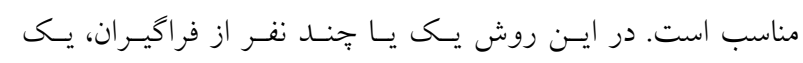

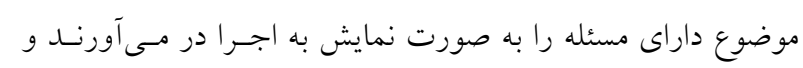

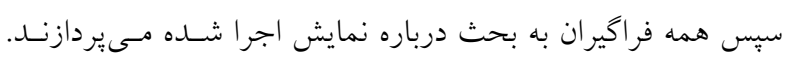

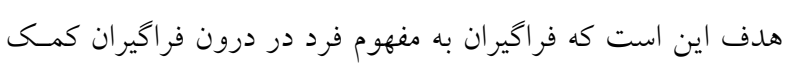

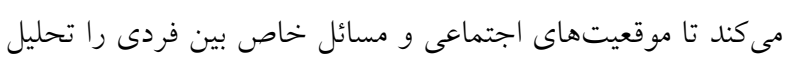

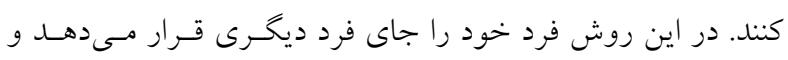

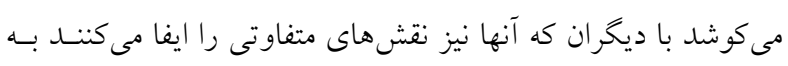

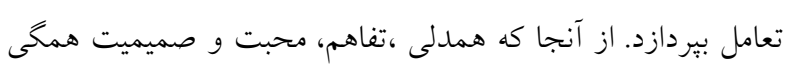

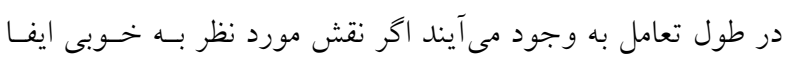

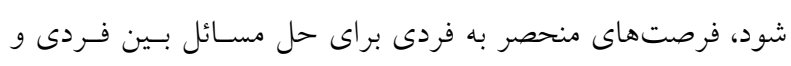

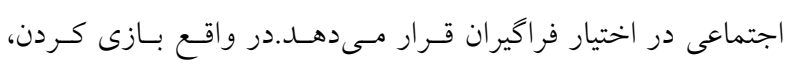

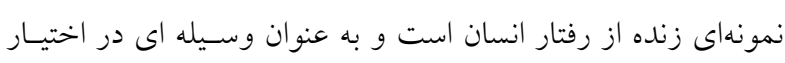

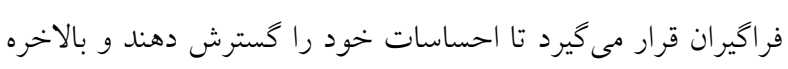

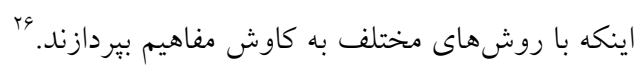

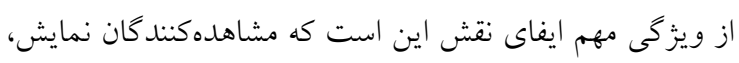

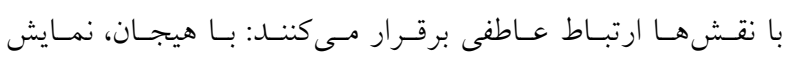

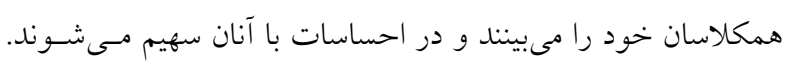

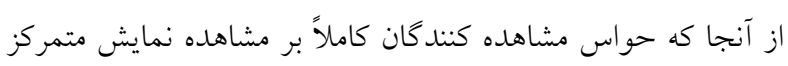

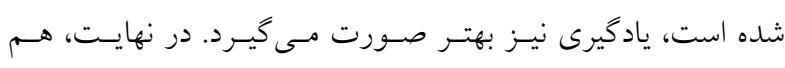

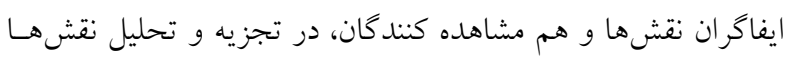
مشاركت خواهند نمود. مراحل اجراى ايفاى نقش: تعبيين موضوع و طرح مسئله: مسئله

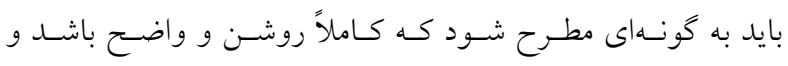


تغيير معنى دارى در نمره موارد مذكور ديده نشد. ^باستفاده از شسيوه

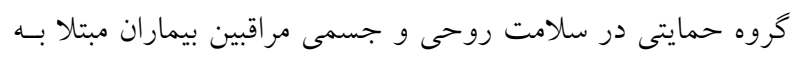

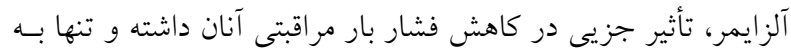

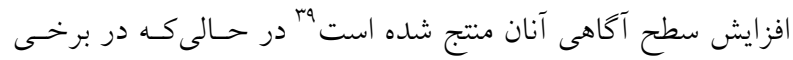
مطالعات، استفاده از اين شيوه در مراقبين بيماران مبتلا به اخستلالات كاتل

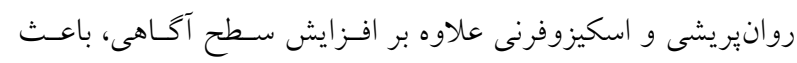
كاهش استرس، فشار بار مراقبتى و رويارويى بهتر در برخورد با اين

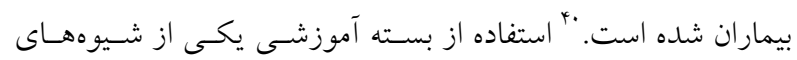

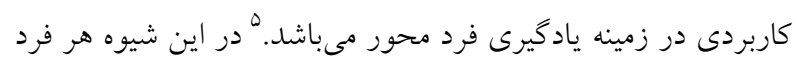

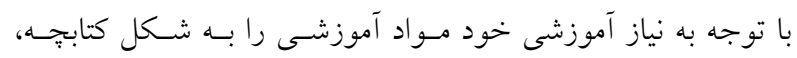

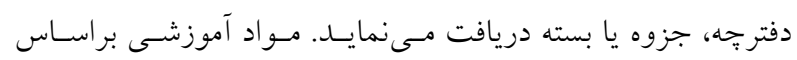

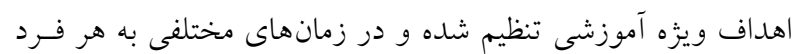

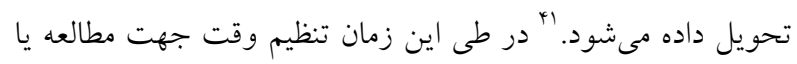

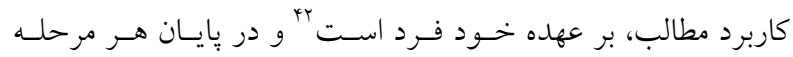
ارزشيابى شفاهى يا كتبى توسط مدرس انجام كردد."

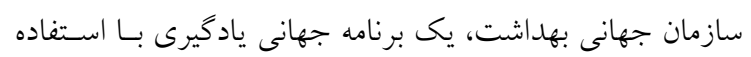

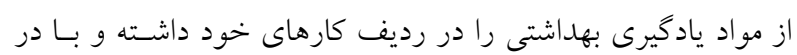

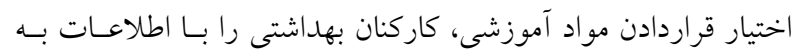

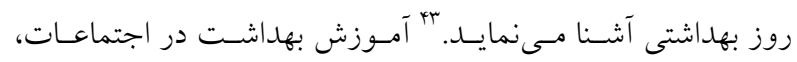
مدارس و محل هاى مراقبت از بيماران و مددجويان ارائه مى خـردد.

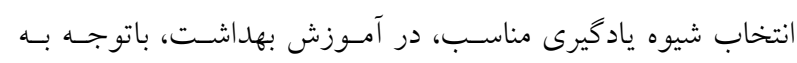

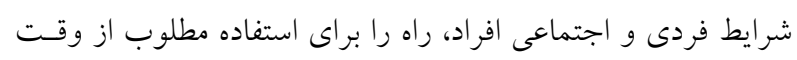

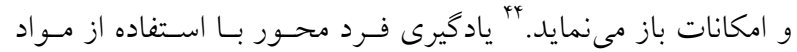

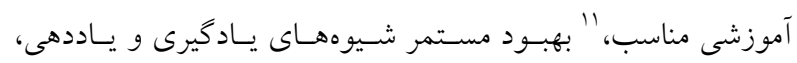

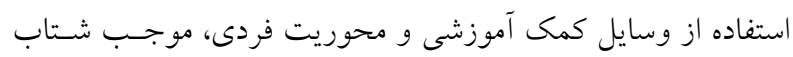
بيشترى در جهت بسط دانش و اطلاعات، به شكلى وسيع در جامعه

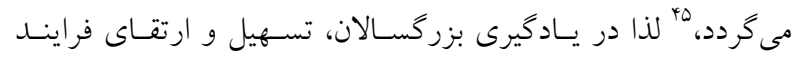

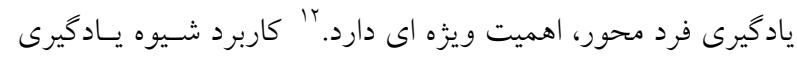
فرد محور موجب توسعه و كسترش دانش و بالا بردن سطح آكـاهى

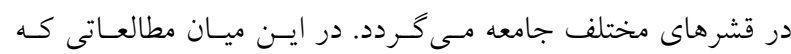

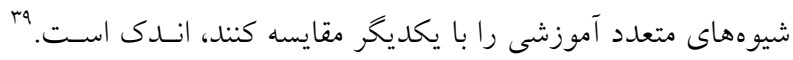

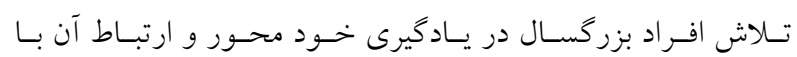

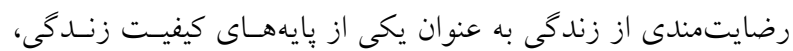

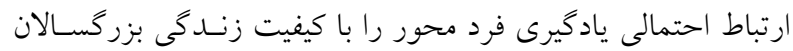

مختلف و با توجه به هدف ها، انخيزههـا، افـراد متفــاوت، امكانـات،

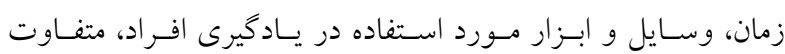

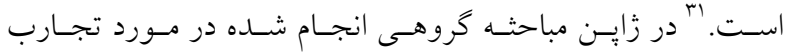
يائسكى، نياز به اطلاعرسانى و آكاه سازى زنان در اين دوران كـاملاُ محسوس است. در اين مباحثه كه توسط Satoh \& Ohashi (ه · (Y)، در رابطه با بررسى نظرات زنان يائسه در كاربرد شيوههاى آموزشى آنى

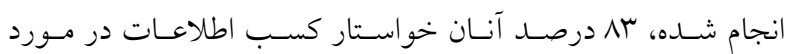
نشانههاى يائسخى و راه كارهاى انطباق بـا آن از طريـق شـيوههـاى مختلف آموزشى بودند. هم جنين در اين زنـان ارتبـاط معنسى دارى بين شدت نشانههاى يائسخى و كاهش كيفيت زندكى ديــده شـد. در ايران، نظرسنجى انتخاب شـيوههـاى آموزشسى در شهرسـتان رى سي

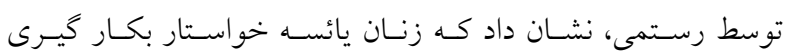
شيوههاى مختلف آموزشى، اعم از شيوه سخنرانى، كروه حمـايتى و آموزش انفر ادى مىباشند.

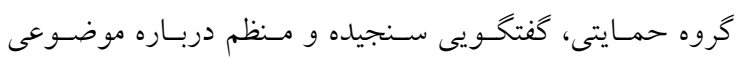
خاص است كه مورد علاقه مشترك شركت كنند آموزشى به عنوان يكى از روشهاى يادكيرى تعاملى شــناخته شـــه

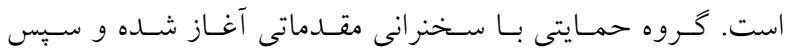
شركت كنندكان به مشـاركت و تعامـل فعـال بـا يكـــيخر در مـورد

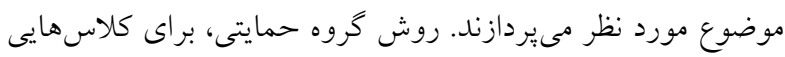

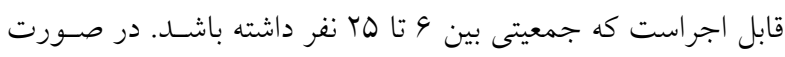
بالا بودن جمعيت كلاس، بايد آنهارا به كروه هاى كـوجكتر تقسئيم

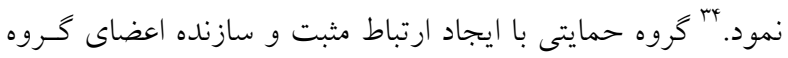

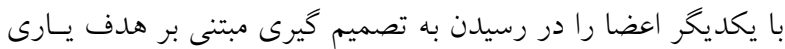

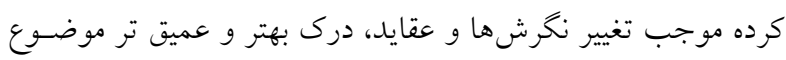
مورد بحث، بسط اطلاعات، ارتقـاى تفكـر انتقـادى و مهـارتهــاى

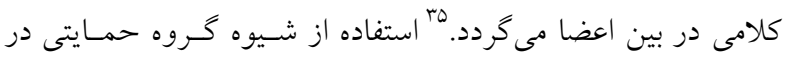
رابطه با كيفيت زندگى به سـبب تبـادل تجـارب فيمـابين افـراد، بـــ

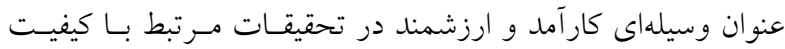

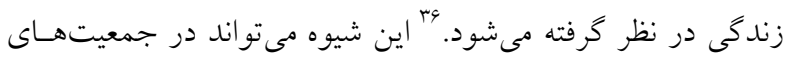

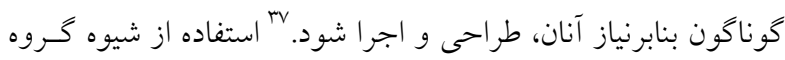

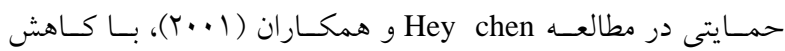

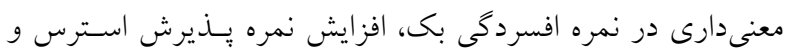
ارزشيابى حمايت ميان فردى همراه بوده، در حالى كه در گروه كنترل 
فرهنگى افراد باشد. "در ضمن كويا و داراى جنان تنوعى باشد كـه

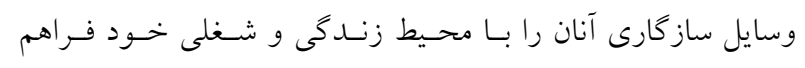

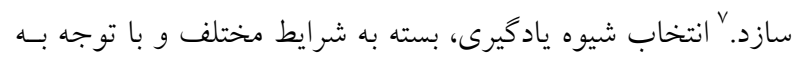

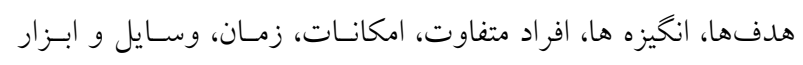$$
\text { مورد استفاده در يادكيرى افراد، متفاوت است. }
$$

\section{References}

1. Harber D. Health promotion and aging practical applications for health professionals, 4nd ed. Springer, New York 2007, p: 30-34.

2. Baskett B, collicott R. preparative cardiovascular risk factor control in elective coronary artery bypass graft patients: A failure of present management 2002;p:10. Available at: http//www pulsus. Com/ Cardiol/ 18.4 / basked.html

3. Kats $S$.The science of quality of life. Outcomes, $6^{\text {th }}$.ed, 2000 . p: 459-675.

4. Jones Gl, Sutton A. Quality of life in obese postmenopausal women. Menopause Int, 2008 ;(14):2632.

5. Taylor $\mathrm{E}$.Teaching and emotions in a non formal educational setting. In: Dirkx J: Adult learning and the emotional self.Wiley, San Francisco 2008, p: 79-86.

6. Nosek $\mathrm{M}$ et al. The effects of perceived stress and Attitudes toward menopause and aging on symptoms of menopause. J Midwifery Women health, 2010; 55(4):328-34.

7. Tierney - Wigg S. The student experience of NETNEP 2008:a personal reflection. Nurse EDUC pract. 2009 ; 9(2):84-5.

8. Regan JA. Motivating students towards self- directed learning. Nurse EDUC Today 2003; 8:593-99.

9. Andragogy as a didactic perspective in the attitudes of nurse instructors in Finland. Nurse EDUC Today 1991; 11(4):287-83.

10. Sharan B. M. Andragogy and self- directed learning: pillars of adult learning theory. Jossey-Bass, unit of John wiley \& sons, Inc. 2001; 89:3-13.

11. Knowles M. Adult learning. Application of adult learning Theory. Robert L. Craig (ed) . development Hand book. NY : MC Graw- Hill 1996; p: 253- 64.

12. Murad H. self directed learning in health professions education medical education review article annul academy of medicine, 2001; 56: 580-91.

13. Brouse C. promotion self-directed learning in three online health promotion and wellness courses. Journal of Authentic learning 2007; 4:25-33.

$$
\begin{aligned}
& \text { نشان مىدهد. "بنابراين، شيوههـاى نـوين آموزشسى كـهـ مبتنى بـر }
\end{aligned}
$$

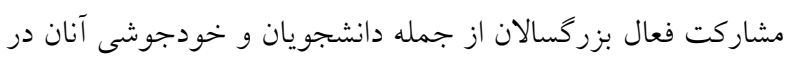

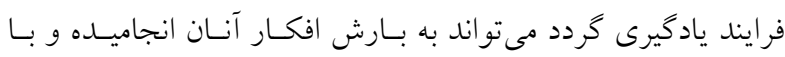

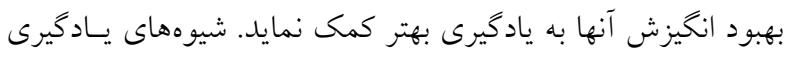

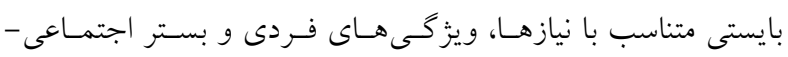

14. Lindsay G, Craing PM. Nursing for public health .1nd ed,. Churchill Livingston, editors, Toronto, 2000; p: 13396.

15. Julia A, Regan M, Hons B, Rgnr, wdn C. motivation students towards self- directed learning. Nurse educ today 2003; 23(8):593-99.

16. Cllwasiw RN. The role of the teacher in self directed learning. Nurse EDUC Today 1987; 7(5):222-27.

17. Kyungsim HN, Alexandra GL. Language learning strategy use of ESL students in an intensive English learning context. System 2006; 34(3):399-415.

18. Taylor $\mathrm{E}$.Teaching and emotions in a non formal educational setting. In: Dirkx J: Adult learning and the emotional self. Wiley, San Francisco 2008, p: 79-86.

19. Lobo G, Kelesey J.Menopause Biology and Pathobiology. Academic press. San Francisco 2001, P: 229-30.

20. Jaao Costa M, Rangacharis P. K. The power of interactive teaching .Biochemistry and molecular Biology Education 2009; 73(2):74-6.

21. Marilynl et al. An educational intervention as decision support for menopause women. Research in nursing \& health 1997; 20:377-87.

22. Kelly M. Teaching for transformation: from learning Theory to teaching strategies. Newsletter on teaching spring 2005; 14(2):2-5.

23. Wood J. simplifying the interface for everyone. Applied ergonomics 1993; 24(1):28-9.

24. Fallahzadeh H. Quality of life after the menopause in Iran: a population study. Maturitas, 2009; 63:51-5136.

25. Safavi. A. Methods and Pattern of Teaching. Tehran publisher 1392.

26. Shaban. H. education skills (Methods and Pattern of Teaching).1390;1(3):32-9.

27. Dent JA . Harden RM. A Practical Guide for MEDICAL TEACHERS. Elsevier 2013.

28. Lowenstein A, Foord-May L, Roomano JC. Teaching Strategies for Health Education and Health Promotion. USA Jones \& Bartlett Publication. 2009. 
29. Nosek $M$ et al. The effects of perceived stress and Attitudes toward menopause and aging on symptoms of menopause. J Midwifery Women health 2010; 55(4):32834.

30. Tierney - Wigg S. The student experience of NETNEP 2008:a personal reflection. Nurse EDUC pract. 2009;9(2):84-5.

31. Regan JA. Motivating students towards self- directed learning. Nurse EDUC Today 2003; 8:593-99.

32. Satoh T, Ohashi K. Quality of life assessment in community - dwelling, middle - aged, healthy women in Japan. Climacteric, 2005; 8:146- 153.

33. FoxyYang S, Sheehan M. Women's perception and experience of menopause: a focus group study. JSPOG, 2000; 16: 215-21.

34. Marilynl et al. An educational intervention as decision support for menopause women. Research in nursing \& health $1997 ; 20: 377-87$.

35. Manoj S. Using focus group in community based rehabilitation. Asia pacific Disabil Rehabil.2005;16 (1): 41-52.

36. Ceremnly J. Focus Group Discussions with older adults and for development of pilot WHOQOL-Old measure. Acta Medic Lituanica. 2003; 10:152-58.

37. Spring R. support groups for people living with HIV/ADIS: A review of literature. JASSOC Nurses AIDS care1998; 9(4):43-55.

38. Hey-Chung C, Ying- Fen T, Shing F, Yaw Wang S.
Effects of support group intervention in postnatally distressed women: A controlled study in Taiwan. J psychosom Res. 2001; 49: 395-99.

39. Herbet R et al. Efficacy of support group program for care- givers of demented patients community: a randomized controlled trial. 2007;7:18.

40. Tong Chien W. The effectiveness and active ingredients of mutual support groups for family caregivers of people with psychotic disorders: a literature review. IJNS, 2009; 46(12): 1604-23.

41. Carolyn $\mathrm{J}$ et al. Introducing a technology - enabled problem- based learning approach in to a health informatics curriculum. EFMI, 2004; 73(5): 173-79.

42. Lwasisw C. The role of teacher in self- directed learning. Edu Tech. 2004; 7:222-27.

43. Kyungsim HN, Alexandra GL. Language learning strategy use of ESL students in an intensive English learning context. System 2006; 34(3):399-415.

44. Patkic $\mathrm{H}$ et al. An innovative outcomes- based medical education program built on adult learning principles medical teacher. Medical Teacher 2006; 28(6): 527-534.

45. Arndt B, Matthiessen P, Osterman T. Engagement of patient in religious and spiritual practices: confirmatory results with the Spreuk-p l.l questionnaire as a tool of quality of life research.BMC, 2005.www.hqlo. Com/ content/ 3/1/53.

46. Anderson G .Self-directed learning readiness and life satisfaction among older adults. A sample quantative research proposal. Washington University. 2003 